\title{
Molecular Identification, Production and Optimization of Pectinase by using Stenotrophomonas maltophilia P9 Isolated from Algal Biomass of Himachal Pradesh, India
}

\author{
Poonam Sharma $^{1 *}$ and Nivedita Sharma ${ }^{2}$ \\ ${ }^{1}$ Microbiology research laboratory, Department of Basic sciences, Dr. Y.S. Parmar University \\ of Horticulture and Forestry, Nauni (Solan) Himachal Pradesh 173230, India \\ ${ }^{2}$ Department of Basic sciences, Dr. Y.S. Parmar University of Horticulture and Forestry, \\ Nauni (Solan) Himachal Pradesh 173230, India \\ *Corresponding author
}

\section{A B S T R A C T}

\begin{tabular}{|l|}
\hline Ke y w o r d s \\
Pectinase, \\
$\begin{array}{l}\text { Optimization, Algal } \\
\text { biomass, Molecular } \\
\text { identification }\end{array}$ \\
\hline Article Info \\
\hline $\begin{array}{l}\text { Accepted: } \\
\text { 06 December } 2017 \\
\text { Available Online: } \\
\text { 10 January } 2018\end{array}$ \\
\hline
\end{tabular}

The demand for enzymes in the global market is projected to rise at a fast pace in recent years. There has been a great increase in industrial applications of pectinase owing to their significant biotechnological uses. Therefore the study was undertaken with aims of; screening pectinase producing bacteria from Rhizoclonium sp. algal biomass collected from different parts of Himachal Pradesh. The isolate P9 with high potential pectinase activity was identified molecularly by sequencing $16 \mathrm{~s}$ rDNA region of the isolate and identified as Stenotrophomonas maltophilia P9 was selected for production. Various optimization steps by using classical one factor at a time approach (OFAT) were carried out to make the production of pectinase enzyme cost effective and commercially viable. The various parameters studied for pectinase production were different media, medium $\mathrm{pH}$, temperature, inoculum size and incubation period. The maximum pectinase production was observed using Adessina et al., (2013) media at initial $\mathrm{pH}$ of 5.0 , at $30^{\circ} \mathrm{C}$ with $10 \%$ inoculum size followed by incubation period of $72 \mathrm{~h}$. In the present study, an attempt was made to isolate efficient pectinase producing bacteria from least explored source of enzymes i.e. algal biomass of Himachal Pradesh and can be further used for various biotechnological applications.

\section{Introduction}

Biotechnological answers for environmental sustainability are modern solutions that help in the growth of the nation and are a boon for the welfare of human beings for the present and forthcoming generations. Biotechnology operations for enzyme production is no longer an academic, it is potentially useful alternative proposition for the future (Mishra et al., 2011). Enzymes are natural catalysts. They are produced by living organisms to increase the rate of an immense and diverse set of chemical reactions required for life. Furthermore, their ability to perform very specific chemical transformations has made them increasingly useful in industrial processes (Li et al., 2012). Pectinase (EC 3.2.1.15) belongs to the class 
hydrolase which are able to hydrolyse pectin more efficient than other Pectinases and their action are very specific, i.e., they acts only on pectin substrates. Pectin is a major constituent of cereals, vegetables, Pectin fibers are complex, high molecular weight heterogeneous and acidic structural polysaccharide. D-galacturonic acid is one of the major components of pectin (Mehta, 2013). Pectinolytic enzymes are classified according to their mode of action on the galacturonan part of the pectin molecule (Semenova et al., 2016). Pectinolytic enzymes can be applied in various industrial sectors wherever the degradation of pectin is required for a particular process. Several microorganisms have been used to produce different types of pectinolytic enzymes (Jayani et al., 2010). Among the various pectinase, bacterial extracellular pectinase are the most significant, compared with animals, plants, viruses and fungal extracellular pectinase.

Extracellular pectinase produced by Bacillus and Cocci species are of main interest from a biotechnology perspective, and are not only in scientific fields of protein chemistry and proteins engineering but also in applied fields such as foods, pharmaceutical and paper industries. Microbial pectinases account for $10 \%$ of the global food and industrial enzyme sales (Jayani et al., 2005; Murad and Azzaz, 2011) and their market is increasing day by day. These are used extensively for fruit juice clarification, juice extraction, manufacture of pectin free starch, refinement of vegetable fibers, degumming of natural fibers, wastewater treatment, and as an analytical tool in the assessment of plant products (Alkorta et al., 2008; Singh et al., 2010). Owing to the enormous potential of pectinase in various sectors of industries whenever degradation of pectin is needed, it is important to undertake research in screening of microorganisms for pectinase and investigate optimal conditions for production of microbial pectinase.
In the light of aforementioned facts, current study was designed to utilize least explored and highly probable source of hydrolytic enzyme producing microorganisms, Rhizoclonium sp. algal biomass as a major source for production of pectinase that ultimately will decrease production cost on commercial scale. Among different isolates, Stenotrophomonas maltophilia P9 capable of producing pectinase was selected and subjected to optimization of different process parameters for producing appreciable levels of pectinase.

\section{Materials and Methods}

\section{Collection of sample and screening of pectinase producing microorganism}

Rhizoclonium sp. algal biomass collected from different sites of Himachal Pradesh in clean polythene bags and was brought to the laboratory. To algal biomass, $1 \%$ solution of pectin powder was added separately. The enriched samples had been serially diluted and plated on to nutrient agar medium supplemented with pectin substrate with initial $\mathrm{pH}$ of 7.0 and incubated at $37^{\circ} \mathrm{C}$ for $2-3$ days. The pure cultures were obtained and maintained at $4^{\circ} \mathrm{C}$ on nutrient agar medium.

\section{Qualitative assay of pectinase}

An extensive screening of bacterial isolates capable of exhibiting appreciable levels of pectinolytic activity was done. The degradation of pectin was estimated by flooding plates with $0.1 \%$ Congo red for 15 min and then washed with $1 \mathrm{~N} \mathrm{NaCl}$ (Teather and Wood 1982).

\section{Quantitative analysis}

The bacterial isolates were screened for the production of extracellular enzymes pectinase activity. Each bacterial isolate was grown in 
nutrient broth at $37^{\circ} \mathrm{C}$ for $24 \mathrm{~h}$. As soon as the substantial growth was observed. Then $5 \mathrm{ml}$ of inoculum was added to $45 \mathrm{ml}$ of nutrient broth supplemented with $1 \%$ of pectin powder. The inoculated flasks were then incubated at $37 \pm 2^{\circ} \mathrm{C}$ for $24 \mathrm{~h}$.

Then, the cell-free supernatant was recovered by centrifugation $\left(10,000 \mathrm{rpm}, 10 \mathrm{~min}\right.$ at $\left.4^{\circ} \mathrm{C}\right)$ and the clear supernatant was used to determine the pectinase enzyme activity.

\section{Pectinase assay (Miller, 1959)}

Pectinase activity was determined using $1 \%$ $(\mathrm{w} / \mathrm{v})$ pectin in $0.2 \mathrm{M}$ citrate buffer $\mathrm{pH} 6.0$ as substrate (Miller, 1959). The released reducing sugars were quantified using a glucose standard curve as a reference. One International Unit (IU) of enzyme activity represents $\mu$ moles of glucose released $/ \mathrm{min} / \mathrm{ml}$ of enzyme.

\section{Determination of total protein}

Total protein content of cell free filtrate was determined by Lowry's method using bovine serum albumin as standard (Lowry et al., 1951).

\section{Molecular identification}

Bacterial isolate P6 was grown overnight at $37^{\circ} \mathrm{C}$ in nutrient broth. The cells were harvested and processed for DNA isolation by conventional method of Sambrook and Rusell (1989). Partial DNA fragment of the 16S rDNA was amplified by polymerase chain reaction (PCR) using gDNA as template.

The universal primers used for amplification were 8F: 5' AGA GTT TGA TCC TGG CTC AG 3' and 1492R: 5' ACG GCT ACC TTG TTA CGA CTT 3'. The phylogeny and family of the bacterial strain was accessed using BLAST search.

\section{Optimization of process parameters}

Various process parameters influencing enzyme production during submerged fermentation were optimized. The strategy followed was to optimize each parameter, independent of the others, and subsequently optimal conditions were employed in all experiments.

In a sequential order, the various process parameters were optimized for maximal enzyme production as follows: fermentation medium, temperature, $\mathrm{pH}$, inoculum size and incubation period by using conventional approach i.e. one factor at a time (OFAT).

\section{Optimization of different media}

Effect of different media i.e. Media I (Adesina et al., 2013), Media II (Joshi et al., 2013), Media III (Kashyapet et al., 2000), Pectin media (Kumar et al., 2012), Nutrient broth pectin (Joshi et al., 2013) were studied for pectinase production.

\section{Effect of different $\mathrm{pH}$}

$\mathrm{pH}$ of the growth media was adjusted from 5.0 to 9.0 to find $\mathrm{pH}$ suitable for fermentation and ultimately for maximum enzyme production. The inoculated broth was incubated for fermentation at $37^{\circ} \mathrm{C}$ for $72 \mathrm{~h}$.

\section{Optimization of different temperature}

In order to attain high enzyme titer, the optimum fermentation temperature was determined by incubating broth media at different temperature ranging from $20^{\circ} \mathrm{C}$ to $45^{\circ} \mathrm{C}(\mathrm{pH} 7.0)$.

\section{Effect of different inoculum size}

Optimum inoculum concentration for enzyme production was studied by varying the 
inoculums concentration $(7.5 \%$ to $17.5 \%)$ in enzyme production medium and incubated at $30^{\circ} \mathrm{C}$ for $72 \mathrm{~h}$.

\section{Time course for pectinase production}

The optimized growth media was inoculated and incubated at $30^{\circ} \mathrm{C}$ for different time intervals ranging from 24 to $144 \mathrm{~h}$ and enzyme activity was measured. Maximum enzyme production was observed in growth medium after $72 \mathrm{~h}$ of incubation.

\section{Statistical analysis}

All the experiments were conducted in triplicates and results are presented as mean. Further the significant differences among the mean values were evaluated by one way ANOVA and using online software tool OPSTAT.

\section{Results and Discussion}

\section{Screening of pectinolytic bacteria}

Based upon Qualitative test, 3 bacteria were found to be positive for pectinase production and produced zone of hydrolysis. To screen out maximum pectinase producer, bacterial isolates were subjected to quantitative assay. In which isolate $\mathrm{P} 9$, produced maximum amount of pectinase as $3.59 \mathrm{IU} / \mathrm{ml}$ (Table 1).

\section{Genotypic identification}

Molecular characterization of the selected pectinase producing strain P9 was done at genomic level by using $16 \mathrm{~S}$ rRNA gene technique Genomic DNA.

Further these amplified 16S rRNA sequences of the bacterial strains was blasted using online tool (mBLAST NCBI). The isolate P9 showed $\quad 96 \%$ homology with Stenotrophomonas maltophilia. The $16 \mathrm{~S}$ rRNA gene sequences of the isolate has been deposited to National Centre for Biotechnology Information (NCBI) gene bank using Bankit program and has been registered in the databases vide accession number Stenotrophomonas maltophilia P9 |MF443881|. The taxonomical identification was done by the phylogenetic tree construction and the comparison of bacterial strain sequences with other homologous bacterial sequences.

\section{Optimization of process parameters}

The pectinolytic bacteria Stenotrophomonas maltophilia P9 was taken for optimization studies through submerged fermentation by varying the media, temperature, $\mathrm{pH}$, inoculum size and incubation period, since the production of pectinase enzyme is influenced by diverse physico-chemical and biological factors.

\section{Effect of media}

Stenotrophomonas maltophilia P9 showed maximum growth in Adessina et al., (2013) medium containing Pectin, $0.3 \mathrm{~g}$, Yeast extract, $1.0 \mathrm{~g}$, Sucrose, $10 \mathrm{~g}, \mathrm{KNO}_{3}, 0.6$, $\mathrm{KH}_{2} \mathrm{PO}_{4}, 1.0 \mathrm{~g}, \mathrm{MgSO}_{4}, 0.25 \mathrm{~g}, \mathrm{CaCl}_{2} .2 \mathrm{H}_{2} \mathrm{O}$, $0.1, \mathrm{~K}_{2} \mathrm{HPO}_{4}, 0.5 \mathrm{~g}, \mathrm{KCL}, 0.5 \mathrm{~g}, \mathrm{dH}_{2} \mathrm{O}-1000$ $\mathrm{ml}, \mathrm{pH}-7.0$. Cell free broth obtained from this medium showed highest enzyme yield of 3.95 IU with a specific activity of $3.16 \mathrm{IU} / \mathrm{mg}$ (Fig. 2).

Other media however, showed lower yields of enzymes which could be attributed to solution of complex ions which might have induced inhibitory effect on enzyme production. Various nitrogen sources, minerals and phosphates like $\mathrm{KH}_{2} \mathrm{PO}_{4}, \mathrm{~K}_{2} \mathrm{HPO}_{4}$ has been found best for pectinase production (Vyas et al., 2005; Narayana et al., 2014; Anuradha et al., 2010). Marcia et al., (2013) have reported a pectinolytic activity of $82.152 \mathrm{U} / \mathrm{ml}$ for strains of Bacillus spp. in Hankin's medium. 
Table.1 Production of pectinase from screened bacteria isolated from Rhizoclonium sp. algal biomass

\begin{tabular}{|l|c|c|c|}
\hline Isolates & Pectinase activity(IU)** & Protein $(\mathbf{m g} / \mathbf{m l}) * * *$ & Specific activity**** \\
\hline P9 & $\mathbf{3 . 5 9}$ & $\mathbf{1 . 7 6}$ & $\mathbf{2 . 0 4}$ \\
\hline P17 & 2.33 & 1.21 & 1.93 \\
\hline P19 & 1.61 & 1.05 & 1.53 \\
\hline C.D.0.05 & 0.87 & 0.49 & N/S \\
\hline S.E.(m) & 0.25 & 0.14 & 0.24 \\
\hline
\end{tabular}

*Enzyme activity (IU): $\mu$ moles of reducing sugars released $/ \mathrm{min} / \mathrm{ml}$ of enzyme

*** Protein concentration: $\mathrm{mg} / \mathrm{ml}$

***Specific activity: enzyme activity/mg of protein

Table.2 Effect of different $\mathrm{pH}$ on pectinase production from Stenotrophomonas maltophilia $\mathrm{P} 9$

\begin{tabular}{|c|c|c|c|}
\hline pH & $\begin{array}{c}\text { Pectinase activity } \\
(\text { IU)* }\end{array}$ & Protein $(\mathbf{m g} / \mathbf{m l}) * * *$ & Specific activity**** \\
\hline $\mathbf{5 . 0}$ & $\mathbf{3 . 9 9}$ & $\mathbf{2 . 3 2}$ & $\mathbf{1 . 7 0}$ \\
\hline $\mathbf{6 . 0}$ & 1.82 & 1.00 & 1.12 \\
\hline $\mathbf{7 . 0}$ & 1.67 & 1.56 & 1.07 \\
\hline $\mathbf{8 . 0}$ & 1.61 & 0.59 & 1.03 \\
\hline $\mathbf{9 . 0}$ & 1.03 & 0.99 & 1.04 \\
\hline CD 0.05 & 0.64 & 0.39 & 0.34 \\
\hline S.E.(m) & 0.20 & 0.12 & 0.11 \\
\hline
\end{tabular}

*Enzyme activity (IU): $\mu$ moles of reducing sugars released/min/ml of enzyme

**Protein concentration: $\mathrm{mg} / \mathrm{ml}$

***Specific activity: enzyme activity/mg of protein

Table.3 Effect of different inoculum size on pectinase production from Stenotrophomonas maltophilia P9

\begin{tabular}{|c|c|c|c|}
\hline $\begin{array}{c}\text { Inoculum size } \\
(\%)\end{array}$ & $\begin{array}{c}\text { Pectinase activity } \\
(\mathrm{IU}) *\end{array}$ & Protein $(\mathrm{mg} / \mathrm{ml}) * * *$ & Specific activity*****| \\
\hline $\mathbf{7 . 5}$ & 2.52 & 1.70 & 1.48 \\
\hline $\mathbf{1 0 . 0}$ & $\mathbf{5 . 9 2}$ & $\mathbf{3 . 1 3}$ & $\mathbf{1 . 7 9}$ \\
\hline $\mathbf{1 2 . 5}$ & 4.04 & 2.54 & 1.59 \\
\hline $\mathbf{1 5 . 0}$ & 1.92 & 1.01 & 1.91 \\
\hline $\mathbf{1 7 . 5}$ & 1.54 & 0.94 & 1.64 \\
\hline C.D.0.05 & 0.70 & 0.40 & N/S \\
\hline S.E.(m) & 0.22 & 0.13 & 0.14 \\
\hline
\end{tabular}

*Enzyme activity (IU): $\mu$ moles of reducing sugars released $/ \mathrm{min} / \mathrm{ml}$ of enzyme

**Protein concentration: $\mathrm{mg} / \mathrm{ml}$

***Specific activity: enzyme activity/mg of protein 
Fig.1 Neighbor-joining tree showing phylogenetic relationship of Stenotrophomonas maltophilia P9 based on a distance matrix analysis of 16S rRNA sequences

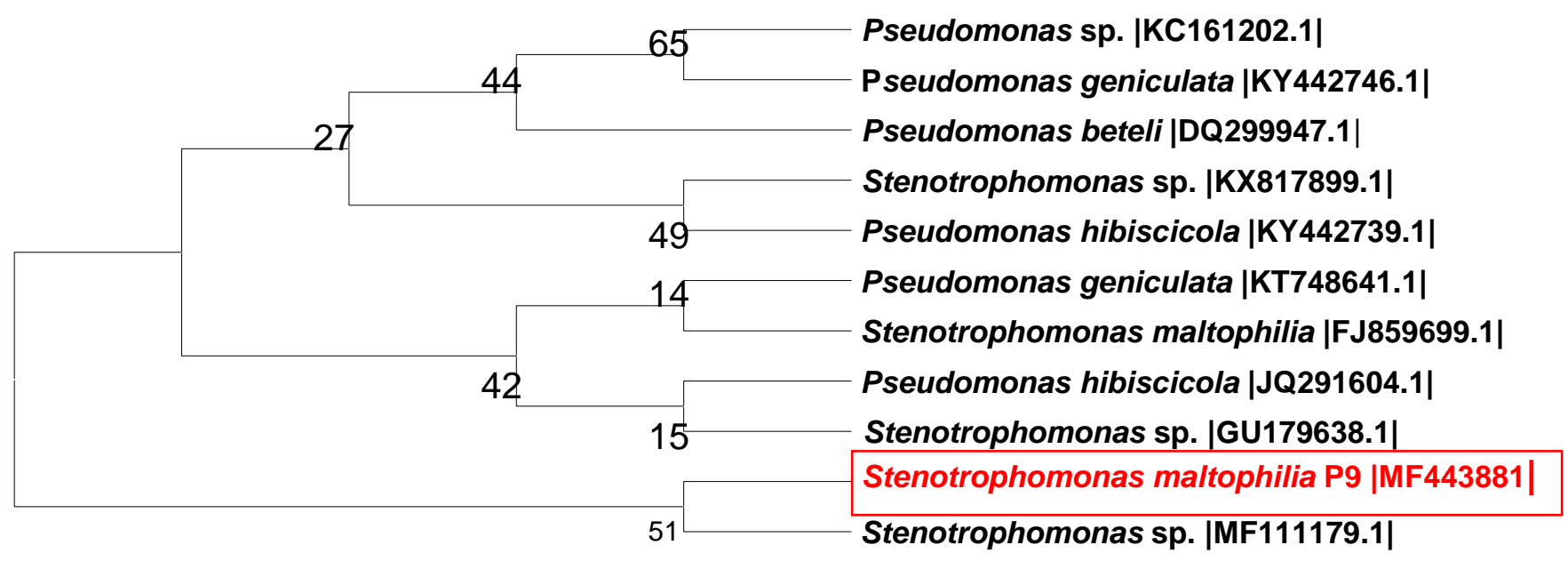

Fig.2 Effect of different media on extracellular Pectinase production from

Stenotrophomonas maltophilia P9

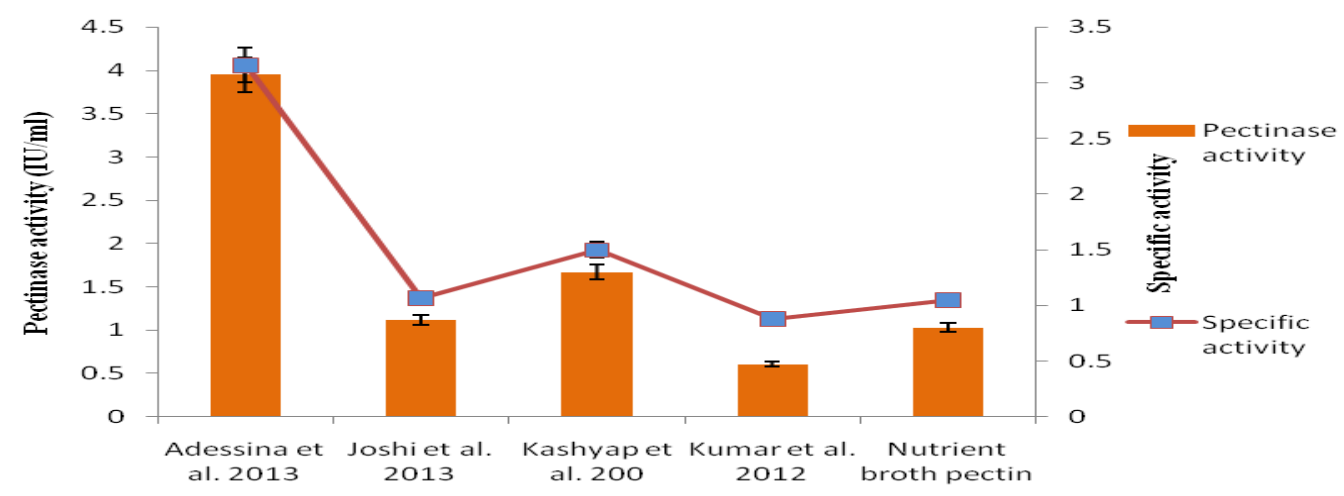

Fig.3 Effect of different temperature on pectinase production from

Stenotrophomonas maltophilia $\mathrm{P} 9$

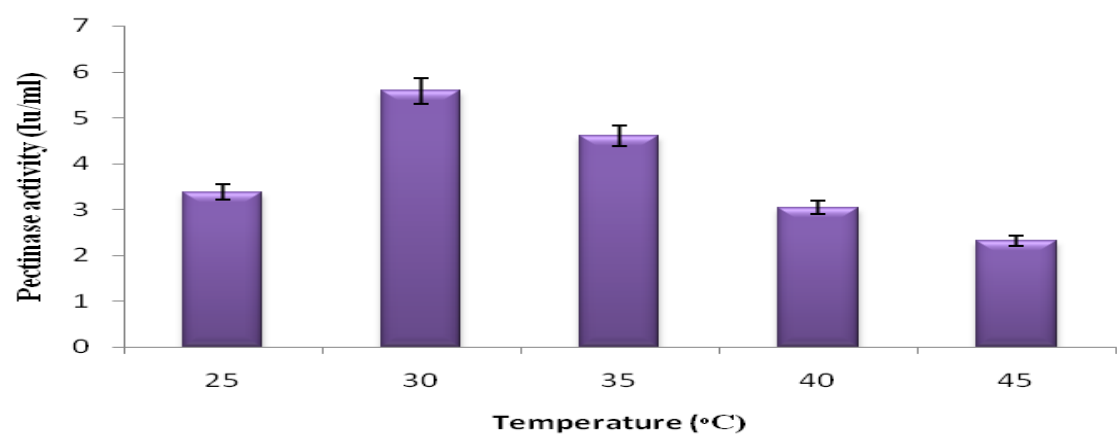


Fig.4 Effect of different incubation time on pectinase production from Stenotrophomonas maltophilia $\mathrm{P} 9$

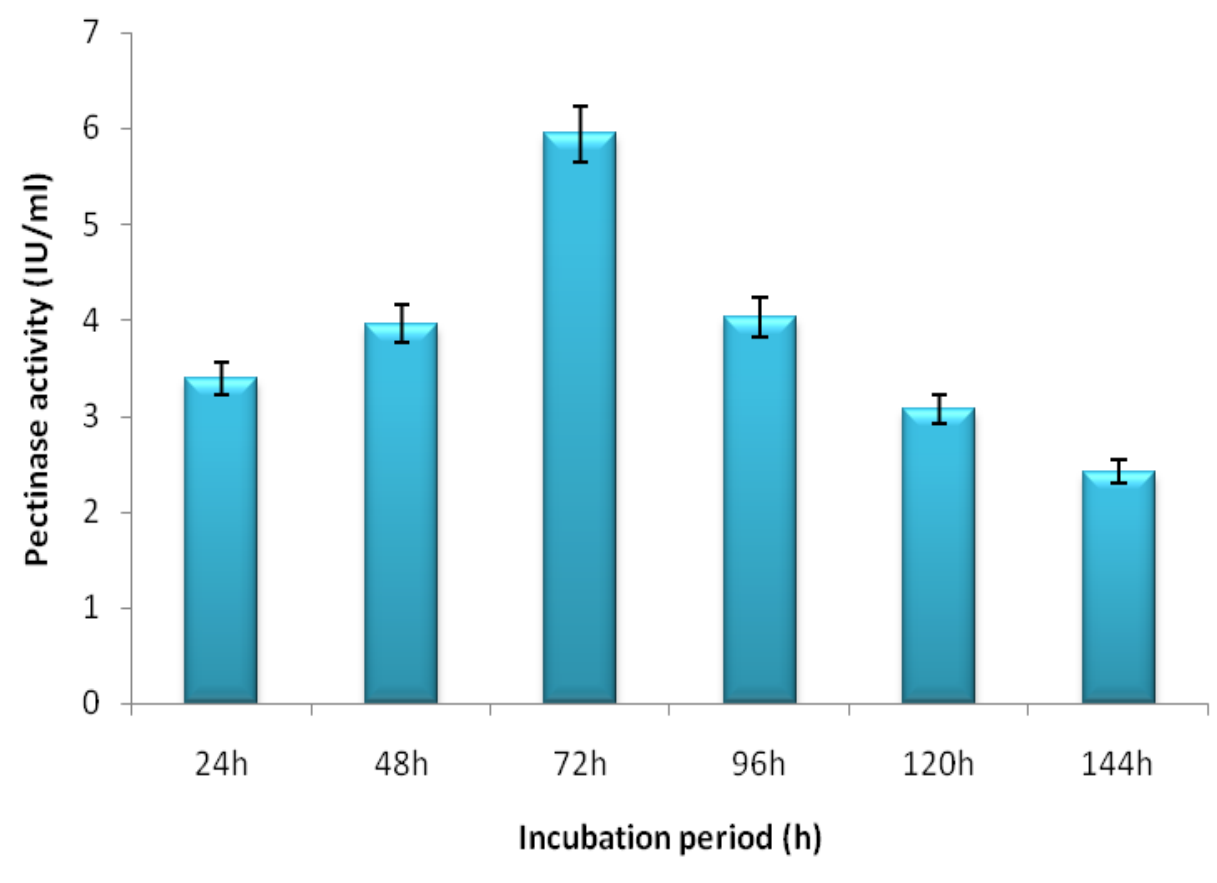

Fig.5 An overview of percent increase in pectinase activity from Stenotrophomonas maltophilia P9 after optimization of different parameters

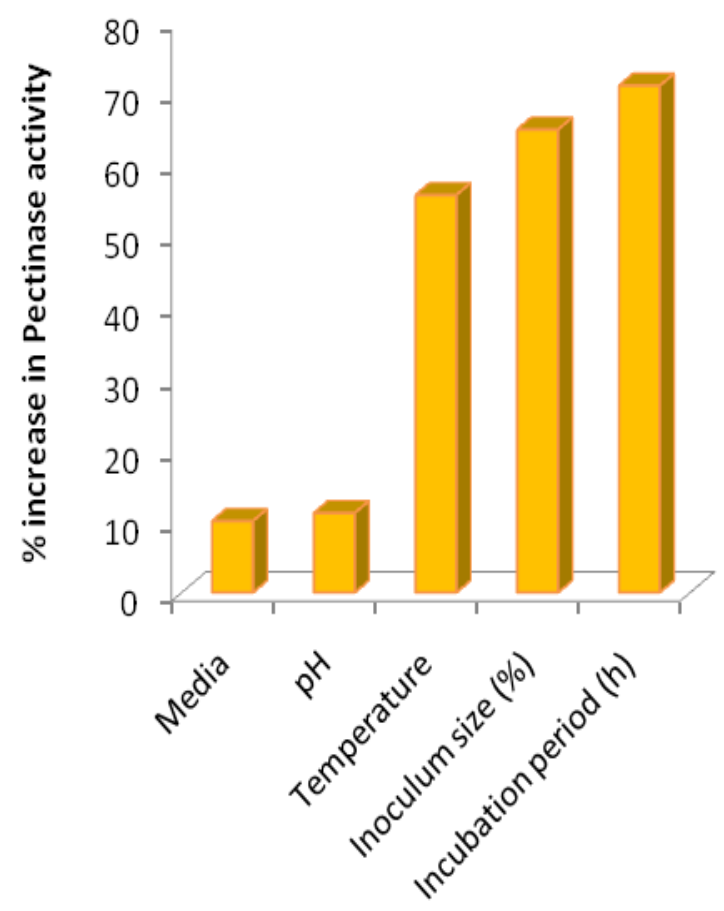




\section{Effect of pH}

Table 2 represents the effect of $\mathrm{pH}$ on the enzyme production potential from Stenotrophomonas maltophilia P9. The highest pectinase activity of 3.99 IU was observed at acidic pH 5.0 with specific activity $1.70 \mathrm{IU} / \mathrm{mg}$. At higher $\mathrm{pH}$ of 7.0 and 8.0 , a respective pectinase activity of $1.67 \mathrm{IU}$ and 1.61 IU has been observed.

This implies that the $\mathrm{pH}$ of the medium influences the growth of microorganisms and hence the enzyme production. Each microorganism possesses a specific $\mathrm{pH}$ range for its growth and activity. Maximum pectinase production $35.84 \mathrm{U} / \mathrm{ml}$ from Bacillus sp. has been reported at $\mathrm{pH} 5.0$ by Laha et al., (2014). Highest pectinase activity $(1.6 \mathrm{IU} / \mathrm{ml})$ was observed at $\mathrm{pH} 6.0$ from Bacillus sp. isolated from vegetable waste soil (Kaur et al., 2016).

\section{Effect of temperature}

Maximum pectinase titres were produced at $30^{\circ} \mathrm{C}$ i.e. (5.59 IU) whereas; least pectinase production was found at $45^{\circ} \mathrm{C}(2.31 \mathrm{IU})$ from Stenotrophomonas maltophilia P9. Incubation temperature is the most important physical factor which affects enzyme production dramatically and their stability. Maximum enzyme activity at optimum temperature may be due to the faster metabolic activity and increase in protein content and extracellular enzyme production in culture supernatant. At very low temperatures, membranes solidify and high temperatures damage microorganisms by denaturing enzymes, transport carriers and other proteins thus lowering enzyme activity (Willey et al., 2008) (Fig. 3).

Kumar et al., (2012) studied the production and optimization of pectinase from Bacillus sp. MFW7 and high pectinase production (1.6
IU/ml) was observed at temperature $35^{\circ} \mathrm{C}$. Nithisha et al., (2016) studied the optimization of pectinase from Bacillus sp. and reported maximum enzyme activity was shown as 40 units $/ \mathrm{ml}$ at optimum temperature $35^{\circ} \mathrm{C}$.

\section{Effect of inoculum size}

The data in Table 3 revealed that optimum inoculum size found to be $10.0 \%(\mathrm{~V} / \mathrm{V})$ for pectinase production revealing $5.92 \mathrm{IU}$. This inoculum size has statistically significant differences over other inoculum sizes. The least pectinase units were recorded at $17.5 \%$ (1.54 IU) as in Table 3 . Thus, it is evident from the data that the enzyme titers were significantly affected by different inoculum sizes.

Highest pectinase titres of 5.92 IU from Stenotrophomonas maltophilia P9 was observed at $10 \%$ inoculum size having statistically significant differences over the range of variable inoculum sizes. There was a steady increase in the enzyme production from 7.5 to $10 \%$ however there was a steep decrease in the enzyme activity beyond this inoculum size because of an overload of the cells in the production medium resulting in nutrient starvation. A lower inoculum size 5\% of has been reported optimum for pectinase production from Bacillus sp. by Hazziz et al., (2013). Venkata et al., (2016) reported an enzyme activity of $136 \mathrm{U} / \mathrm{ml}$ from $B$. circulans at an inoculum size of $5 \%$.

\section{Effect of different incubation period}

To determine the effect of incubation period on pectinase production from Stenotrophomonas maltophilia P9, enzyme activity was measured at regular intervals from $24 \mathrm{~h}$ to a period of $144 \mathrm{~h}$ (Fig. 4). Highest pectinase activity was measured at $72 \mathrm{~h}$ (6.94 IU) from followed by gradual 
decline on either side. Least enzyme production was observed at $144 \mathrm{~h}(2.42 \mathrm{IU})$ of fermentation time. Statistically enzyme production was found significantly higher at $72 \mathrm{~h}$ than others timings.

Afterwards incubation beyond $72 \mathrm{~h}$ resulted in a decreased enzyme activity that could be due to depletion of nutrients available causing a stressed microbial physiology eventually resulting in an inactivation of enzyme (Flores et al., 1997). Maximum yield of pectinase (40 $\mathrm{U} / \mathrm{ml}$ ) was obtained after $72 \mathrm{~h}$ incubation from Bacillus sp. isolated from soil by Nithisha et al., (2016). Venkata and Diwakar (2013) found that 48 hours was the optimum duration for maximum pectinase enzyme activity (166U/ml) from Bacillus circulans isolated from dump yards of vegetable wastes. Above this period the pectinase enzyme activity started to decrease. In case of pectinase production enzyme activity increased from 3.95 IU to 6.94 IU and 75.69 percent increase was noticed in pectinase production after optimizing different process parameters as shown in Figure 5. Classical approach for one Variable at a time (OVAT) used in the present enzymes optimization study has resulted in an increase in the production of different enzymes proving the direct utility of this technique in increasing enzyme titers.

In the current study a pectinase producing bacteria Stenotrophomoans maltophilia P9 was isolated from Rhizoclonium sp. algal biomass collected from different sites of Himachal Pradesh. Laboratory scale optimization of different conditions for enhanced eznyme production by carried out by classical one factor at a time approach (OFAT). The maximum productivity of pectinase achieved by optimized process parameters such as temperature $30^{\circ} \mathrm{C}, \mathrm{pH} 5$, incubation time $72 \mathrm{~h}$, inoculum size $10 \%$ was 6.94 IU. It can be concluded from the above studies, Stenotrophomonas maltophilia P9 based on its capability to produce pectinase could be considered as potential candidate for industrial applications and this genus is first time reported for pectinase production. Moreover the study also reveals the values as well as the microbial wealth of pectinase producing bacteria which can be a boon for the development of biotechnological processes. However, these parameters have to be tested in mass cultures in automated incubators so as to confirm the optimum conditions for enzyme production for industrial application.

\section{References}

Adesina, F.C., O.A. Adefila, A. Olutola, O. Adeyefal, H. O. Ummi and Agunbiade S. O. 2013. Production of pectinase by fungi isolated from degrading fruits and vegetable. Nature and Science. 11: 102108.

Alkorta, I., G. Garbisu, M. J. Llama and Serra, J.L. 2008. Industrial applications of pectic enzymes: a review. Process Biochemistry. 33: 21-28.

Aneja, K.R. 2003. Experiments in microbiology, plant pathology and biotechnology. $3^{\text {rd }}$ ed. New Age International Ltd., New Delhi. 254p.

Anuradha, K., P.N. Padma, S. Venkateshwar and Gopal, R. 2010. Selection of nutrients for polygalacturonase production by Aspergillus awamori MTCC 9166 using Plackett- Burman design. Indian Journal of Biotechnology 13:502-507.

Flores, M.E., R. Perez and Huitron, C. 1997. $\beta$-xylosidase and xylanase characterization and production by Sreptomyces species CH-M-1035. Letters of Applied Microbiology. 24: 410-416.

Hazziz, E., D.J. Ravinda, K. Mariappan, J. Akil, M. Kumar and Jayaraj, R.L. 2013. 
Production of extracellular pectinase by Bacillus cereus isolated from market solid waste. Journal of Bioanalysis and Biomedicine. 3: 70-75.

Jayani, R. Singh, S. Saxena and Gupta R. 2005. Microbial Pectinolytic Enzymes:

A Review. Process Biochemistry. 40: 2931-2944.

Jayani, R. Singh, S.K. Shukla and Gupta R. 2010. Screening of Bacterial Strains for Polygalacturonase Activity: Its Production by Bacillus Sphaericus (MTCC 7542). Enzyme Research. 30: 67-85.

Joshi, M., M. Nerurkar and Adiv, A.R. 2013. Use of Citrus limetta peels for pectinase production by marine Bacillus subtilis. Innovative Romanian Food Biotechnology. 12: 75-83.

Kashyapet, D.R., P.K. Vohra, S. Chopre and Tewari, R. 2000. Applications of pectinases in the commercial sector: a review. Bioresource Technology. 77: 215-227.

Kaur, S., H.P. Kaur, B. Prasad and Bharti T. 2016. Production and optimization of pectinase by Bacillus sp. isolated from vegetable waste soil. Indo American Journal of Pharmaceutical Research. 6: 1-6.

Kumar, M.D.J., G.M. Saranya, K. Suresh, P.D. Andal, R. Rajakumar and Kalaichelvan, P.T. 2012. Production and optimization of pectinase from Bacillus sp. MFW7 using cassava waste. Asian Journal of Plant Science and Research. 2: 369-375.

Laha, S., D. Sarkar and Chaki, K. 2014. Optimization of production and molecular Characterization of pectinase enzyme produced from Penicillium chrysogenum 2:326-335.

Li, S., X. Yang, S. Yang, M. Zhu and Wang X. 2012. Technology Prospecting on Enzymes: Application, Marketing and Engineering. Computational and
Structural Biotechnology Journal. 2(3): 9-17.

Lowry, O.H., N.J. Rosebrough, A.L. Farr and Randall RJ. 1951. Protein measurement with the Folin-phenol reagent. Journal of Biology and Chemistry. 193:265275.

Marcia, M.C.N., R. Soares, Silva da and Eleni, G. 2013. Screening or Bacterial strains for Pectinolytic activity characterization of the Polygalacturonase produced by Bacillus sp. Review in Microbiology. 30: 299303.

Mehta, S., M. Rana, N. Nilofer and Patel N. 2013. Optimization of Physiological Parameters for Pectinase Production From Soil Isolates and Its Applications in Fruit Juice Clarification. Journal of Environmental Research and Development. 7(4): 1539-1546.

Miller, G.H. 1959. Use of dinitrosalicylic acid reagent for determination of reducing sugar. Annals of Chemistry. 31: 426429.

Mishra K., S. Vuppu, and Bishwambhar S. 2011. An Overview of Some Reported Soil Enzyme Producing. Indian Journal of Fundamental Applied Life Sciences. 1(4): 180-186.

Murad, H. and Azzaz, H.H. 2011. Microbial Pectinases and Ruminant Nutrition. Research Journal of Microbiology. 6: 246-269.

Narayana, M., V. Rangarajan, A. Mani and Srinivasan B. 2014. Statistical designing of enriched pectin extract medium for the enhanced production of pectinase by Aspergillus niger. International Journal of Pharmacy and Pharmaceutical Sciences. 6: 666-672.

Nithisha, K.T., S. Lavanya, B. Shivaji and Mahesh, M. 2016. Isolation, purification and characterization of pectinase. European Journal of Biomedical and Pharmaceutical sciences. 9: 438-443. 
Semenova, M.V., O.A. Sinitsyna, V.V. Morozova, E.A. Fedorov and Okunev, O.N. 2016. Applied Biochemistry and Microbiology. 42: 598-602.

Singh, S.A., M. Ramakrishna and Rao, A.G. 2010. Optimization of downstream processing parameters for the recovery of pectinase from the fermented broth of Aspergillus carbonarious. Process Biochemistry. 35: 411-417.

Teather, R.M. and Wood, P.J. 1982. Use of Congo red-polysaccharide interactions in enumeration and characterization of cellulolytic bacteria from bovine rumen. Applied Environmental Microbiology. 43: 777-780.

Venkata, E., N. Rajuand and Divakar, G. 2016. Production of pectinase by using Bacillus circulans isolated from dump yards of vegetable wastes. International journal of Pharmaceutical Science and Research. 4: 2615-2622.

Venkata, N.R.E. and Divakar, G. 2013. Production of pectinase by using Bacillus circulans isolated from dump yards of vegetable wastes. International Journal of Pharmaceutical Sciences and Research. 4(7): 2615-2622.

Vyas, A., D. Vyas and Vyas, K.M. 2005. Production and optimization of cellulases on pretreated groundnut shell by Aspergillus terreus AV49. Journal of Scientific and Industrial Research 64: 281-286.

Willey, J.M., L.M. Sherwood and Woolverton, C.J. 2008. Prescott, Harley and Kleins Microbiology, $7^{\text {th }}$ ed. McGraw Hill Co. Inc., Boston. p.48.

\section{How to cite this article:}

Poonam Sharma and Nivedita Sharma. 2018. Molecular Identification, Production and Optimization of Pectinase by using Stenotrophomonas maltophilia P9 Isolated from Algal Biomass of Himachal Pradesh, India. Int.J.Curr.Microbiol.App.Sci. 7(01): 670-680. doi: https://doi.org/10.20546/ijcmas.2018.701.082 